\title{
POSSIBILITIES OF OBTAINING ZINC AND IRON AFTER LEACHING OF GALVANIC SLUDGES
}

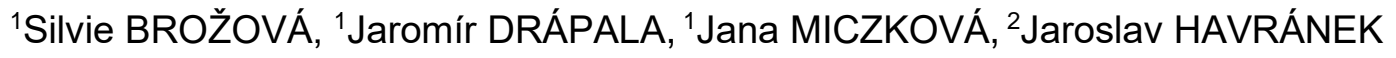 \\ ${ }^{1}$ VSB - Technical University of Ostrava, Ostrava, Czech Republic, EU, silvie.brozova@vsb.cz \\ 2VITKOVICE CYLINDERS a.s., Ostrava, Czech Republic, EU, jaroslav.havranek@cylinders.cz
}

https://doi.org/10.37904/metal.2020.3629

\begin{abstract}
The paper deals with the possibility of obtaining zinc and iron from waste sludge and filter cakes, which are formed during galvanic plating. It contains a theoretical analysis of hydrometallurgical processes. The practical part describes the samples and their leaching in acids under different conditions. At the end of the work, the highest yield of zinc and iron in the leaching product in the leaching substance is evaluated.
\end{abstract}

Keywords: Zinc and iron, galvanic sludge, hydrometallurgical processes, leaching

\section{INTRODUCTION}

The sources for the production of metals include ore raw materials. These must be processed by means of treatment processes into the form of a concentrate, which serves as an input raw material for the production of a specific metal. There are several ways to produce metals, e.g. using pyrometallurgical, hydrometallurgical or electrometallurgical processes. The production itself is followed by refining processes.

The basic processes of metal production include hydrometallurgical processes. These are based on the leaching of pretreated enriched ore, which is most often sulphate roasted, to obtain sulphates which are readily soluble in suitable leaching agents. The product is two phases, leaching substance - a solid residue and a leach, which contains the metal of interest. We then obtain the metal from the leach using a number of processes. With a relatively rich input raw material, the amount of metals still appears in the leaching substance, which can be further leached using leaching agents; we obtain a leach again and depleted waste leaching substance. The previously described procedures are applied to recover from metals from the leach.

The aim of the work is to obtain zinc and iron from leaching of galvanic sludges. A partial goal is a theoretical analysis of hydrometallurgical processes. The aim of the practical part is to modify the sample, followed by leaching of sewage sludge in acids. At the end of the work, it is evaluated which conditions enable to achieve the highest yield of zinc and iron after leaching of galvanic sludges [1-8].

\section{ESSENTIAL CHARACTERISTICS OF GALVANIC SLUDGES AND LEACHING PROCESS}

Metal recovery from ores by hydrometallurgical processes are under way at relatively low temperatures up to approximately $200{ }^{\circ} \mathrm{C}$. If the process takes place up to temperatures of $100{ }^{\circ} \mathrm{C}$ and a total pressure of 0.1 $\mathrm{MPa}$, we speak of leaching under standard conditions. However, if the process takes place at elevated temperatures, it automatically requires an increase in total pressure. Then the process is located in a pressure reactor - autoclave, and it is the case of pressure leaching.

Galvanic sludges, which contain more significant amounts of heavy metals, form wastes that are suitable for recycling. These arise during the treatment of wastewater from the operation of the electroplating plant. It is a mixture of metal hydroxides, mainly iron, zinc, chromium, and others. The sludge is sedimented in the reaction wells and, after sedimentation, is pumped into the sludge sump. From there, they are drained in a sludge press by a sludge pump. Subsequently, dewatered sludge is formed, which is accumulated in containers. 
Hydrometallurgical methods are used for sludge treatment. Acidic or basic leaching is used to convert the metals of interest into the leachate. Most waste matter does not dissolve in the given environment or change to a form of a compound that is difficult to dissolve. The leach is then processed by selective methods in order to separate the individual metals [9-15].

Leaching is the selective recovery of one or more components from a solid concentrate (ore) into a liquid leach. From a physico-chemical point of view, it is a heterogeneous process involving at least two phases: solid (s) and liquid (I) [16]. An important factor influencing the course of leaching is the ratio of liquid to the solid phase, referred to as sludge $\mathrm{K}: \mathrm{P}$, i.e. the ratio of the leaching solution to ore. In order to obtain the highest possible concentration of metal in the leachate, the K:P ratio should be as small as possible. With increasing concentration, the leaching deteriorates, so in each case, the highest leachate concentration must be [17].

\section{EXPERIMENTAL}

The aim of the experimental part was to obtain zinc and iron after leaching of galvanic sludges. Leaching was performed in sulfuric, hydrochloric and nitric acids at different temperatures and time intervals.

The main part of the experimental work was to determine the most suitable conditions for achieving the maximum yield of zinc and iron.

The samples were analyzed for zinc and iron content in the laboratories of the Faculty of Materials Science and Technology.

The input chemical analysis of the sample is in Table 1.

Table 1 The amount of metals of interest in galvanic sludges measured by ED-XRF

\begin{tabular}{|c|c|c|c|c|}
\hline \multicolumn{4}{|c|}{ Galvanic sludges } \\
\multirow{2}{*}{ Element } & 1 & 2 & 3 & \multirow{2}{*}{ Average } \\
\cline { 2 - 5 } & 15.93 & 15.95 & 15.84 & 15.91 \\
\hline Zn & 12.30 & 12.31 & 12.30 & 12.30 \\
\hline Fe & \multicolumn{3}{|c|}{ Measurement (wt\%) } \\
\hline
\end{tabular}

Waste sludge samples were pretreated by drying under normal conditions and size homogenization by hand grinding (Figure 1).



Figure 1 Preparation of samples for leaching 
Three acids were selected for the leaching method: sulfuric, nitric and hydrochloric. This selection was made according to the analysis of literature sources that deal with the leaching of waste materials. Leaching solutions were prepared from concentrated acids by dilution to a $2 \mathrm{M}$ solution.

The leaching took place in $2 \mathrm{M}$ acids without the addition of an oxidizing agent, with the addition of $\mathrm{H}_{2} \mathrm{O}_{2}$ and with the addition of ozone, at temperatures of 40 and $60{ }^{\circ} \mathrm{C}$ for 6 hours.

\section{Leaching procedure}

The beakers with the prepared samples $(200 \mathrm{ml}$ of $2 \mathrm{M}$ acids together with $50 \mathrm{~g}$ of the weighted sample, ratio 1:4) were placed on electromagnetic stirrers. The required temperatures $\left(40^{\circ} \mathrm{C}\right.$ and $\left.60^{\circ} \mathrm{C}\right)$ were set individually on each electromagnetic stirrer. After a set time $(6 \mathrm{~h})$, the leaching process was completed, and the leaching substance and the leach were separated by filtration.

Table 2 The final zinc and iron content of the leaching substance

\begin{tabular}{|c|c|c|c|c|}
\hline & addition & acids & Zn (wt\%) & Fe(wt\%) \\
\hline $1-25{ }^{\circ} \mathrm{C}-6 \mathrm{~h}$ & - & $\mathrm{H}_{2} \mathrm{O}$ & 16.44 & 11.97 \\
\hline $2-40{ }^{\circ} \mathrm{C}-2 \mathrm{~h}$ & - & $\mathrm{H}_{2} \mathrm{SO}_{4}$ & 1.93 & 1.29 \\
\hline $3-40{ }^{\circ} \mathrm{C}-4 \mathrm{~h}$ & $\mathrm{H}_{2} \mathrm{O}_{2}$ & $\mathrm{H}_{2} \mathrm{SO}_{4}$ & 1.89 & 0.77 \\
\hline $4-40{ }^{\circ} \mathrm{C}-6 \mathrm{~h}$ & $\mathrm{O}_{3}$ & $\mathrm{H}_{2} \mathrm{SO}_{4}$ & 3.33 & 2.39 \\
\hline $5-60{ }^{\circ} \mathrm{C}-2 \mathrm{~h}$ & - & $\mathrm{H}_{2} \mathrm{SO}_{4}$ & 1.18 & 0.73 \\
\hline $6-60{ }^{\circ} \mathrm{C}-4 \mathrm{~h}$ & $\mathrm{H}_{2} \mathrm{O}_{2}$ & $\mathrm{H}_{2} \mathrm{SO}_{4}$ & 1.54 & 0.68 \\
\hline $7-60{ }^{\circ} \mathrm{C}-6 \mathrm{~h}$ & $\mathrm{O}_{3}$ & $\mathrm{H}_{2} \mathrm{SO}_{4}$ & 1.27 & 0.92 \\
\hline $8-40{ }^{\circ} \mathrm{C}-2 \mathrm{~h}$ & - & $\mathrm{HNO}_{3}$ & 3.92 & 3.76 \\
\hline $9-40{ }^{\circ} \mathrm{C}-4 \mathrm{~h}$ & $\mathrm{H}_{2} \mathrm{O}_{2}$ & $\mathrm{HNO}_{3}$ & 3.19 & 4.75 \\
\hline $10-40{ }^{\circ} \mathrm{C}-6 \mathrm{~h}$ & $\mathrm{O}_{3}$ & $\mathrm{HNO}_{3}$ & 4.63 & 4.70 \\
\hline $11-60{ }^{\circ} \mathrm{C}-2 \mathrm{~h}$ & - & $\mathrm{HNO}_{3}$ & 5.64 & 12.53 \\
\hline $12-60{ }^{\circ} \mathrm{C}-4 \mathrm{~h}$ & $\mathrm{H}_{2} \mathrm{O}_{2}$ & $\mathrm{HNO}_{3}$ & 6.62 & 9.69 \\
\hline $13-60{ }^{\circ} \mathrm{C}-6 \mathrm{~h}$ & $\mathrm{O}_{3}$ & $\mathrm{HNO}_{3}$ & 6.03 & 12.07 \\
\hline $14-40{ }^{\circ} \mathrm{C}-2 \mathrm{~h}$ & - & $\mathrm{HCl}$ & 6.06 & 12.56 \\
\hline $15-40{ }^{\circ} \mathrm{C}-4 \mathrm{~h}$ & $\mathrm{H}_{2} \mathrm{O}_{2}$ & $\mathrm{HCl}$ & 5.60 & 13.48 \\
\hline $16-40{ }^{\circ} \mathrm{C}-6 \mathrm{~h}$ & $\mathrm{O}_{3}$ & $\mathrm{HCl}$ & 6.17 & 12.65 \\
\hline $17-60{ }^{\circ} \mathrm{C}-2 \mathrm{~h}$ & - & $\mathrm{HCl}$ & 5.12 & 12.50 \\
\hline $18-60{ }^{\circ} \mathrm{C}-4 \mathrm{~h}$ & $\mathrm{H}_{2} \mathrm{O}_{2}$ & $\mathrm{HCl}$ & 5.15 & 12.54 \\
\hline $19-60{ }^{\circ} \mathrm{C}-6 \mathrm{~h}$ & $\mathrm{O}_{3}$ & $\mathrm{HCl}$ & 4.16 & 10.88 \\
\hline
\end{tabular}

The samples obtained after leaching (leaching substance, leach) were chemically analyzed for the zinc and iron content. (Tables 2 and 3).

Table 3 The resulting content of zinc and iron in the leach

\begin{tabular}{|c|c|c|c|c|}
\hline & addition & acids & $\mathbf{Z n}(\mathrm{g} / \mathrm{l})$ & $\mathbf{F e}(\mathrm{g} / \mathrm{l})$ \\
\hline $1-25^{\circ} \mathrm{C}-6 \mathrm{~h}$ & - & $\mathrm{H}_{2} \mathrm{O}$ & 0.044 & 0.011 \\
\hline $2-40^{\circ} \mathrm{C}-2 \mathrm{~h}$ & - & $\mathrm{H}_{2} \mathrm{SO}_{4}$ & 21.6 & 12.9 \\
\hline $3-40{ }^{\circ} \mathrm{C}-4 \mathrm{~h}$ & $\mathrm{H}_{2} \mathrm{O}_{2}$ & $\mathrm{H}_{2} \mathrm{SO}_{4}$ & 25.0 & 14.6 \\
\hline $4-40{ }^{\circ} \mathrm{C}-6 \mathrm{~h}$ & $\mathrm{O}_{3}$ & $\mathrm{H}_{2} \mathrm{SO}_{4}$ & 31.5 & 18.5 \\
\hline
\end{tabular}




\begin{tabular}{|c|c|c|c|c|}
\hline $5-60{ }^{\circ} \mathrm{C}-2 \mathrm{~h}$ & - & $\mathrm{H}_{2} \mathrm{SO}_{4}$ & 18.6 & 9.89 \\
\hline $6-60{ }^{\circ} \mathrm{C}-4 \mathrm{~h}$ & $\mathrm{H}_{2} \mathrm{O}_{2}$ & $\mathrm{H}_{2} \mathrm{SO}_{4}$ & 23.5 & 12.8 \\
\hline $7-60^{\circ} \mathrm{C}-6 \mathrm{~h}$ & $\mathrm{O}_{3}$ & $\mathrm{H}_{2} \mathrm{SO}_{4}$ & 31.8 & 18.3 \\
\hline $8-40^{\circ} \mathrm{C}-2 \mathrm{~h}$ & - & $\mathrm{HNO}_{3}$ & 22.9 & 12.3 \\
\hline $9-40^{\circ} \mathrm{C}-4 \mathrm{~h}$ & $\mathrm{H}_{2} \mathrm{O}_{2}$ & $\mathrm{HNO}_{3}$ & 25.4 & 14.1 \\
\hline $10-40{ }^{\circ} \mathrm{C}-6 \mathrm{~h}$ & $\mathrm{O}_{3}$ & $\mathrm{HNO}_{3}$ & 26.1 & 14.3 \\
\hline $11-60^{\circ} \mathrm{C}-2 \mathrm{~h}$ & - & $\mathrm{HNO}_{3}$ & 36.8 & 4.22 \\
\hline $12-60^{\circ} \mathrm{C}-4 \mathrm{~h}$ & $\mathrm{H}_{2} \mathrm{O}_{2}$ & $\mathrm{HNO}_{3}$ & 37.7 & 0.54 \\
\hline $13-60{ }^{\circ} \mathrm{C}-6 \mathrm{~h}$ & $\mathrm{O}_{3}$ & $\mathrm{HNO}_{3}$ & 32.4 & 0.39 \\
\hline $14-40^{\circ} \mathrm{C}-2 \mathrm{~h}$ & - & $\mathrm{HCl}$ & 31.3 & 0.13 \\
\hline $15-40^{\circ} \mathrm{C}-4 \mathrm{~h}$ & $\mathrm{H}_{2} \mathrm{O}_{2}$ & $\mathrm{HCl}$ & 27.3 & 0.01 \\
\hline $16-40{ }^{\circ} \mathrm{C}-6 \mathrm{~h}$ & $\mathrm{O}_{3}$ & $\mathrm{HCl}$ & 36.2 & 0.05 \\
\hline $17-60^{\circ} \mathrm{C}-2 \mathrm{~h}$ & - & $\mathrm{HCl}$ & 30.4 & 0.07 \\
\hline $18-60{ }^{\circ} \mathrm{C}-4 \mathrm{~h}$ & $\mathrm{H}_{2} \mathrm{O}_{2}$ & $\mathrm{HCl}$ & 26.1 & 0.01 \\
\hline $19-60{ }^{\circ} \mathrm{C}-6 \mathrm{~h}$ & $\mathrm{O}_{3}$ & $\mathrm{HCl}$ & 31.6 & 0.01 \\
\hline
\end{tabular}

\section{CONCLUSION}

The aim of this work was to obtain zinc and iron from the leaching of galvanic sludge. The waste sludge sample was treated and leached in a solution of sulfuric, nitric and hydrochloric acids in several stages. In four stages, the amount of zinc increased evenly with temperature. This amount was recorded in $\mathrm{g} / \mathrm{l}$. The iron also grew steadily with temperature in these stages, but at $60^{\circ} \mathrm{C}$, there were sudden weight fluctuations, both at 2 and 6 hours of leaching. Only when leached in water for 6 hours and at a temperature of $40^{\circ} \mathrm{C}$, there was almost no increase in the amount of zinc or iron.

From the overall summary, it was clear that the smaller the K:P ratio, the higher the metal recovery. In this case, it was $1: 4$, i.e. $50 \mathrm{~g}$ of sample and $200 \mathrm{ml}$ of $2 \mathrm{M}$ acids. The use of an autoclave could be most suitable for leaching due to the shorter leaching time and the highest possible metal recovery.

\section{ACKNOWLEDGEMENTS}

\section{The paper has been done in connection with the project SS01020312, Preparation and optimization of properties of alloys for automotive, electrical and biomedical applications and their recycling SP2019/128 and SP2019/43.}

\section{REFERENCES}

[1] BROŽOVÁ, Silvie, INGALDI, Manuela, ŠPERLÍN, Ivan. Economical aspects of high-temperature heating utilization for industrial waste treatment. In METAL 2013:22 ${ }^{\text {nd }}$ International Conference on Metallurgy and Materials, Ostrava: TANGER, 2013, pp. 1735-1739.

[2] BARICOVA, Dana, PRIBULOVA, Alena, ROSOVA, Andrea. Steelmaking slag - waste or valuable secondary raw material. In $13^{\text {th }}$ International Multidisciplinary Scientific Geoconference, SGEM 2013 Albena, BULGARIA. 2013, Book Series: International Multidisciplinary Scientific GeoConference SGEM. 2013, pp. 437-442.

[3] MIHOK, Lubomir, BARICOVÁ, Dana. Recycling of oxygen converter flue dust into oxygen converter chargé. Metalurgija. 2003, vol. 42, no. 4. pp. 271-275.

[4] VONTOROVÁ, J., VÁŇOVÁ, P. Determination of carburized layer thickness by GDOES method. AIMS Materials Science. 2018, vol. 5, no. 1, pp. 34-43. DOI: 10.3934/matersci.2018.1.34. WOS:000428531900002 
[5] VONTOROVÁ, J., MOHYLA, P. Use of GDOES method for evaluation of the quality and thickness of hot dip galvanised coating. Transactions of the Institute of Metal Finishing. 2018, vol. 96, no. 6, pp. 313-318. DOI: 10.1080/00202967.2018.1520531, WOS:000447137500007

[6] Utilization of electroplating sludge as subgrade backfill materials: Mechanical and Environmental Risk Evaluation. Publishing Open Access research journals \& papers. Hindawi [online], [cit.3.6.2020]. Available from: https://www.hindawi.com/journals /ace/2018/4891418/

[7] MISHRA, B., LUDWIG, Ch., DAS, S.ed. REWAS 2008: Global Symposium on Recycling, Waste, Treatment and Clean Technology. 2008. ISBN 978-0-87339-726-1.

[8] XU Y., LI J., LIU L., Current status and future perspective of recycling copper by hydrometallurgy from waste printed circuit boards. Procedia Environmental Sciences. 2016, vol. 31, pp. 162-170.

[9] ŠEVČíKOVÁ, Xenie. Mechanical and corrosion properties of galvanically deposited zinc-based coatings: dissertation abstract. Ostrava: VŠB - Technical University of Ostrava, 2012. ISBN 978-80-248-2789-6.

[10] Study on the environmental risk assessment of lead-acid batteries. Science, Health and Medical Journals. full text articles and books [online]. [cit.1.6.2020]. Available from: https://www.sciencedirect.com/science/article/pii/S1878029616

[11] https://www.statista.com/statistics/1067081/generation-electronic-waste-globally-forecast/, 28.05.2020

[12] KARDAS, Edyta, BROZOVÁ, Silvie. Situation in waste treatment in Poland. In METAL 2013 - 22 ${ }^{\text {nd }}$ International Conference on Metallurgy and Materials. Ostrava: TANGER, 2013, pp 1773-1778

[13] Liquid waste treatment in galvanizing and zinc electroplating. Industrial waste water \& air treatment [online], [cit. 20.4.2020]. Available from: https://blog-en.condorchem.com/treatment-waste-electroplating-industry-zinccoatings/\#.Xth46udS9PZ

[14] HARIKRUSHNAN, B., SHREYASS, G., HEMANT, G., PANDIMADEVI, M., Recovery of metals from printed circuit boards (PCBs) using a combination of hydrometallurgical and biometallurgical processes. Int. J. Environ. Res. 2016, vol. 10, no. 4, pp. 511-518.

[15] CHAUHAN, G., JADHAO, P.R., PANT, K.K., NIGAM, K.D.P. Novel technologies and conventional processes for recovery of metals from waste electrical and electronic equipment: Challenges \& opportunities - A review. Journal of Environ. Chem. Eng. 2018, vol. 6, no. 1, pp. 1288-1304.

[16] DIMITRIJEVIĆ, S., IRAN, J. Recycling of precious metals from E-scrap. Iranian Journal of Chemistry and Chemical Engineering. 2013, vol. 32, no. 20, pp. 17-23.

[17] KRIŠTOFOVÁ, Dana. Precious Metal Recycling. Ostrava: VŠB - Technical University of Ostrava. 2001. ISBN 807078-939-5. 